Georgia State University

ScholarWorks @ Georgia State University

\title{
"A Kiss for Mother, A Hug for Dad": The Early 20th Century Parents' Day Campaign
}

\author{
Ralph LaRossa \\ Georgia State University, rlarossa@gsu.edu \\ Jaimie Ann Carboy
}

Follow this and additional works at: https://scholarworks.gsu.edu/sociology_facpub

Part of the Sociology Commons

\section{Recommended Citation}

Ralph LaRossa and Jaimie Ann Carboy. '"A Kiss for Mother, A Hug for Dad': The Early 20th Century Parents' Day Campaign," Fathering: A Journal of Theory, Research, and Practice about Men as Fathers, 2008, vol. 6, pp. 249-266.

This Article is brought to you for free and open access by the Department of Sociology at ScholarWorks @ Georgia State University. It has been accepted for inclusion in Sociology Faculty Publications by an authorized administrator of ScholarWorks @ Georgia State University. For more information, please contact scholarworks@gsu.edu. 


\title{
"A Kiss for Mother, A Hug for Dad": The Early 20th Century Parents' Day Campaign
}

\author{
Ralph laRossa Jaimie Ann Carboy \\ Georgia State University
}

\begin{abstract}
Father's Day and Mother's Day occupy sacred positions in American society - at least today. Unbeknownst to many, however, there was a campaign in the 1920s and 1930s to change Father's Day and Mother's Day to Parents' Day, so that fathers and mothers would be honored on the same day. The campaign, based in New York City, was essentially a debate about the cultural position of parents in American society. How the campaign came to be-and why, in the end, it failed-illustrate the political maneuvering that characterizes people's efforts to draw symbolic boundaries around fatherhood and motherhood.
\end{abstract}

Keywords: Parents' Day, Father's Day, Mother's Day, fatherhood, motherhood, holidays, commemoration, collective memory, symbolic boundaries, U.S. history, New York City

In 1994, the cartoonist for the comic strip, B.C., prodded readers to contemplate why there was a Father's Day to pay tribute to men, and a Mother's Day to pay tribute to women, and not a combined holiday to simultaneously pay tribute to both. "Splittingup the two don't make sense," mused a Stone Age character, writing on a tablet while sitting under a tree. "To celebrate them singly, you gotta buy 2 cards, and separate gifts can be no small expense. Why not honor mom and dad together - as a 'team'!" An image we should proudly reinforce!" (Harte, 1994).

As humorous as the concept of combining Father's Day and Mother's Day may have been to B.C. readers, the fact is the very same notion had been proposed, in all seriousness, over 70 years before. Unbeknownst to many, there was a campaign in the 1920 s and 1930s to change Father's Day and Mother's Day to Parents' Day, so that fathers and mothers would be honored on the same day. The campaign, based in New

Ralph LaRossa and Jaimie Ann Carboy, Department of Sociology, Georgia State University.

This work was supported, in part, by a grant from the National Science Foundation (SES-8812583). We thank Alexis Bender, Pamela Priddy Daniels, Betty Anne Simons Gordon, Maureen Mulligan LaRossa, and Saori Yasumoto for their assistance.

Correspondence concerning this article should be addressed to Ralph LaRossa, Department of Sociology, Georgia State University, P.O. Box 5020, Atlanta, GA 30302-5020. Electronic mail: rlarossa@gsu.edu

Fathering, Vol. 6, No. 3, Fall 2008, 249-266.

(C) 2008 by the Men's Studies Press, LLC. http://www.mensstudies.com. All rights reserved. fth.0603.249/\$12.00

DOI: $10.3149 /$ fth.0603.249

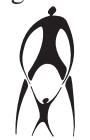


York City, was essentially a debate about the cultural position of parents in American society. How the campaign came to be-and why, in the end, it failed-illustrate the political maneuvering that characterizes people's efforts to draw symbolic boundaries around fatherhood and motherhood.

Relying on reports in the New York Times, we chronicle the events leading up to and supporting the debate about the holiday. Our goal is not only to shed light on a little-known campaign and broaden people's understanding of the history of fatherhood and motherhood, but also to contribute to a growing body of research on the societal aspects of memorializing (see Zerubavel, 1997, 2003). On a theoretical plane, the early 20th century Parents' Day campaign is a case study in the social construction of commemoration.

To gather information about Parents' Day, we examined every article in the New York Times Index that, between 1900 and 1950, had been categorized under "Parents' Day," "Father's Day," or "Mother's Day." We looked beyond the Parents' Day articles to contextualize Parents' Day and to ensure that we did not overlook write-ups about Parents' Day that might have been (and were) grouped under the other holidays. (We did not start out searching for articles on Parents' Day, but discovered them while investigating the history of fatherhood.)

One limitation to our study is that we have no reports from other newspapers in New York. While the New York Times is readily accessible (issues going back to 1851 are now online), other newspapers from the era (e.g., New York Herald Tribune, New York Daily Mirror, Brooklyn Daily Eagle) are not as conveniently available. (For a discussion of the pros and cons of relying on newspaper data in the study of collective action, see Earl, Martin, McCarthy, \& Soule, 2004.) We also do not have archival materials pertaining to the Parents' Day campaign - items that might have revealed the behind-the-scenes attitudes and behaviors of the campaign's participants. We searched for these materials, but were unable to find anything of value.

\section{Remembering Fathers and Mothers}

To fully comprehend the Parents' Day campaign, it is important to be familiar with the chronology of Father's Day and Mother's Day. Both holidays figure significantly in the creation and eventual demise of Parents' Day. (For historical accounts on Father's Day and Mother's Day, see LaRossa, 1997; Schmidt, 1995.)

The official story of Father's Day is that Sonora Louise Smart Dodd of Spokane, Washington, envisioned a national day of commemoration for fathers in honor of her own father, William Jackson Smart, who raised six children after the death of his wife. Dodd pitched her idea for the holiday to the local Ministerial Association and Young Men's Christian Association (YMCA) and, with their support, orchestrated the first Father's Day celebration in 1910. Dodd had hoped that Father's Day would be held on June 5th, which was her father's birthday, but the ministers told her they could not prepare their specialized sermons in time (apparently she had approached the ministers in late spring), so the observance was moved forward two weeks to the third Sunday in June. It is this day that Americans now recognize as Father's Day. 
The official story of Mother's Day credits Anna M. Jarvis of Philadelphia as the holiday's founder. Jarvis was the daughter of Anna Reeves Jarvis who, in 1868, had organized a Mothers' Friendship Day in Grafton, West Virginia, to reunite families separated during the Civil War. The elder Jarvis's goal was to expand the friendship day into a memorial day for mothers throughout the nation. Her version of the holiday was often spoken of in the plural rather than the singular possessive - as Mothers' Day versus Mother's Day - because the commemoration originally was intended to be "a vehicle for organized social and political action by all mothers, not for celebrating the private services of one's own particular mother" (Coontz, 1992, p. 152).

Anna Reeves Jarvis died in 1905, before the holiday could be established on a nationwide scale. In 1908, however, her daughter, working with friends, was able to persuade churches in both Grafton and Philadelphia to dedicate their services to mothers on the second Sunday in May. This day (May 10th in 1908) was the closest Sunday to when Anna Reeves Jarvis had passed away (May 9th), and it is the day that continues to mark the celebration of Mother's Day.

Although the modern (singular possessive) versions of Father's Day and Mother's Day were born about the same time, Mother's Day was more quickly embraced. In 1914, the U.S. Congress officially designated the second Sunday in May as Mother's Day. The same level of government recognition, however, was not accorded Father's Day until 1972 (Father's Day, Public Law, 1972). This does not mean that Father's Day was not celebrated prior to then. It means simply that Congress did not see fit to put the two holidays in the same cognitive space, though the President did issue a Father's Day proclamation each year. By the 1930s, Father's Day had become lodged in the nation's psyche thanks, in large part, to the machinations of the business community.

Our use of the phrase, "official story," when referring to these accounts, is deliberate, because, even though both are commonly accepted genealogies, they do not convey all that occurred. Frequently disregarded is the fact that not everyone was keen on the idea of a Father's Day and a Mother's Day when they were first proposed. One man, writing to the New York Times in 1914, sardonically asked if there was to be a Father's Day, why should there not also be an Uncle's Day, or Brother's Day, or Household Pet Day? When Mother's Day was brought to the floor in the U.S. Senate in 1908, it also was not universally endorsed, with some arguing that the holiday might lead to a slew of memorial days, among them an Aunt Day or a Cousin Day (LaRossa). Thus, however "sacred" the two holidays may appear to be today, they were not always viewed that way.

In the beginning, the very existence of Father's Day and Mother's Day was thrown into doubt. People had to work not only to formulate the holidays but also to legitimate them (i.e., justify them). If Father's Day and Mother's Day are viewed as socially constructed realities, they, like all social realties, are made plausible and valid in and through the political efforts of various individuals and interest groups to make them so. These efforts often come down to how people talk about the holidays, for it is through discourse, more than through other modes of interaction, that social realities are objectivated (see Berger \& Luckmann, 1966). Likewise, attempts to alter social realities 
often involve a "struggle over the production of mobilizing and countermobilizing ideas and meanings" (Benford \& Snow, 2000, p. 613).

Although Mother's Day had a rocky start, the fact that it was quickly put into law might suggest that its status in the early 20th century was inviolate. And although Father's Day was not "legally" equal to Mother's Day, the fact that it had become, in a matter of decades, an American institution would seem to have made it impervious to challenge as well. Yet 15 to 20 years after the holidays were first proposed, a campaign emerged to join Father's Day and Mother's to create Parents' Day. How could that happen?

\section{The Beginnings of the Parents’ Day Campaign}

Parents' Day was conceived in the 1920s by Robert Spero (sometimes also referred to as Robert Spere). Admired for his work with the disabled, the 60-plus-yearold Spero was a "children's radio entertainer" and philanthropist who often could be seen around New York City distributing "toys, gadgets and candy from an apparently limitless supply in his pockets." Like media stars nowadays, Spero would adopt a fictive persona when he performed. To many in the metropolitan area, he was known simply as "Uncle Robert." In his philanthropy, Spero typically chose to remain anonymous and operated under the auspices of the "Uncle Robert Foundation." (see "Happiest couple sought," 1936; "Many celebrations mark Mothers' Day," 1923; "Parents Day fete planned," 1931).

Asked how the concept of Parents' Day came to him, Spero replied that he was inspired during a Mother's Day party he had organized for the elderly poor on the city's Welfare Island in the 1920s. "Seeing those forgotten parents," he once declared, "those broken lives bent with age, the stories of bitter disappointments written on their careworn faces, made me realize that there still appeared among them a will to be happy" ("Walker to deliver tribute to parents," 1932). Exactly how this realization translated into a desire to reconfigure Mother's Day is unclear, but the implication is that the festivities made him think that fathers deserved to be honored along with mothers.

Spero's tale about the creation of Parents' Day may have been heartfelt. There is reason, however, to believe that other forces were at work, too. The initial impetus behind Parents' Day is rooted in the fact that Spero's "New York Committee for the Celebration of Mother's Day" was prevented in 1923 from sponsoring a Mother's Day parade and meeting at the City College of New York. Anna M. Jarvis, who by then was widely recognized as the founder of Mother's Day and was the president of the Philadelphia-based "Mother's Day International Association," put a halt to Spero's Mother's Day festivities. Jarvis argued that the New York Committee had no right to hold a parade, indeed "had no right to celebrate Mother's Day" at all, because Mother's Day was her holiday ("Drop Mother's Day plan," 1923). Unable to hold his event in Manhattan, Spero "carried his celebration to 900 women inmates of the Home for Aged on Welfare Island" ("Many celebrations mark Mothers' Day"). The disagreement over who had the authority to celebrate Mother's Day thus appears to have been the spark that ignited the Parents' Day efforts. 
One may well wonder why, if Spero was so interested in paying tribute to fathers, he did not throw his support behind Father's Day. The business community probably would have welcomed his backing, given how much it was working to promote the holiday (especially during the Depression). Yet, in the campaign's public activities, Spero made no mention of Father's Day. One possible explanation is that, since he ran into trouble when he tried to celebrate Mother's Day, he wanted to avoid any confrontation with others who might claim "ownership" of a men's commemoration day. Another possibility is that he was infatuated with the idea of there being a holiday that only he would be credited with founding.

Although Spero was the principal spokesperson for Parents' Day, he was not alone in his support of such a commemoration. In a 1916 letter to the editor of the New York Times, Henry Woodward Hulbert of Groton, Connecticut, called for the abolition of all existing family-connected holidays and the establishment of a "Home Day" to honor fathers and mothers and children together ("Why Not a Home Day?," 1916). In 1929, Parents' Magazine publisher George Hecht penned "an editorial message" in which he, too, suggested refashioning Father's Day and Mother's Day into Parents' Day. “A Parents' Day," he wrote, "would foster in children a proper recognition and appreciation of the unselfish devotion and self-sacrifice of both mothers and fathers." Hecht added: "We have no quarrel with the fine sentiment that creates a Mother's Day but we feel that the significance of that day will be immeasurably greater if Mother's Day became Parents' Day - its dual purpose, the honoring of their parents on the part of children and the dedication of fathers and mothers to the great ideal of creating throughout the country an enlightened parenthood" (Hecht, 1929).

That someone as influential as Hecht would lend his name to the campaign is significant, but what is even more significant is that Hecht was not only an early proponent of Parents' Day but also a principal player in its demise. (We will have more to say about this in a moment.)

\section{The Rise and Fall of the Parents' Day Campaign}

The Parents' Day campaign may have been conceived in the 1920s, but it was not until the 1930s that it gained momentum. A critical point came when New York State Assemblyman Julius S. Berg of the Bronx introduced a bill to establish the holiday. Said Berg: "I feel convinced that the mothers will be glad to share with the fathers whatever good may come both materially and in tributes. Surely nothing is to be lost and much is to be gained by honoring both together."

The assemblyman was not the only politician or public figure to tout the idea. Berg announced that, among other luminaries, his bill had the "approval of President [Herbert] Hoover, Senator Robert F. Wagner of New York, Mayor [Jimmy] Walker, Governor [Franklin D.] Roosevelt, the American War Mothers, the Clergy Club, [and] the Grand Lodge of Elks" ("Says mothers favor day for both parents," 1930; also "Public hearing for 'Parents' Day,"” 1930). 
It is difficult today to imagine any politician, much less the President of the United States and the Mayor of New York, taking a position against Mother's Day. That the American War Mothers and members of the clergy would be in favor of renaming Mother's Day is surprising as well. Their actions speak directly to the question, how much legitimacy did Mother's Day have in the 1930s?

The legitimation of a holiday or of any social object develops over time (see Berger \& Luckmann; also Blumer, 1969). At first, a holiday may not seem "logical" or "natural," and it may be challenged. This was true for Father's Day and Mother's Day; both initially drew jeers. The supporters of both, however, countered by speaking on the holiday's behalf, offering emotional testimonials about what fathers and mothers didnot just for their own children but for the country - to warrant such recognition. In 1914, the supporters of Mother's Day succeeded in getting the federal government on their side; but even so, the legitimation of the holiday was not automatic. More verbal work had to occur, especially the verbal work of parents when they taught their children about the holiday. (A key phase in the legitimation of an institution is the transmission of that institution to a new generation.)

By repeatedly being confirmed, a holiday becomes more of a social fact-more "objectively real." Those who were not around when a holiday was first proposed only know that it exists. They may not be familiar with how it came to be; they may not actually care. Some, especially the young, may believe it has always existed. Still, in order for the holiday to continue and for its legitimation to remain or increase, continuous verbal work is required. Thus, whenever people acknowledge the holiday and act toward the holiday as if it has meaning, they are socially re-creating the holiday.

A holiday that has the highest level of legitimacy would not be challenged. A holiday that has a high, but not the highest, level of legitimacy might be challenged, but the chances are the opposing forces would be defeated. A holiday that has a moderate level of legitimacy might also be challenged, but now it would be more of a tossup as to who would win. And so on. The fact that Mother's Day and implicitly Father's Day were being questioned in the 1920s and 1930s would suggest that the holidays were perceived not to have the highest level of legitimacy.

A clue as to why Mother's Day may not have been held in the utmost regard comes from Anna M. Jarvis. To her and many others, Mother's Day had become too commercialized-more sacrilegious than sacrosanct. Jarvis did try to stop this process. In 1934, she succeeded in keeping the U.S. Post Office from using the phrase "Mother's Day" on a three-cent stamp in honor of the painting, "Whistler's Mother." She felt that the stamp "was just another racket” ("Mother's Day, Inc.," 1938). Years later, in 1944, Jarvis distributed thousands of celluloid flower buttons to churches and schools, and asked that they be sold or given away. Her hope was that the celluloid buttons would decrease the Mother's Day demand for fresh-cut flowers and reduce the floral industry's profits ("Second Sunday in May," 1944). (Other pro-Mother's Day groups disagreed with Jarvis's position. In 1924, the American War Mothers maintained that Mother's Day was “a day of public recognition of motherhood for all, not under the control of one organization" ["Mothers at odds on day," 1924]. It interesting that, six years later, the American War Mothers would come out in favor of Parents' Day.) 
As for Father's Day, when Spero began his campaign in the mid 1920s, the position of the holiday was shaky at best. Telling is the fact that between 1915 and 1923 the Times did not print a single report on any Father's Day activity.

It is important to consider the possibility that the Parents' Day campaign may have been not so much a direct assault on Mother's Day as it was a veiled attack on mothers. At different points in history, women have been deemed to be inadequate caregivers, criticized for making sons "soft" and for smothering children in general. The Boy Scout movement was founded at the turn of the 20th century "to rescue boys from their mothers and reunite them with a virile ideal," while the "unmanliness of those rejected by the military" during World War II was attributed to "mothers' overprotectiveness" (Kimmel, 1996, pp. 168, 229). The Parents' Day campaign was not manifestly anti-mother, but more than coincidence may have been behind the campaign reaching its zenith during the Depression, when, in the wake of wholesale unemployment, women were regularly blamed for men's travails (Evans, 1989, pp. 201-201).

In 1931, Spero announced that the "annual celebration of Parents' Day" would be held in Central Park on the afternoon of Mother's Day, May 10th. "More than 40,000 children, representing most of the public schools of the city are expected to be present, as well as the parents of many," reported the New York Times. Addressing the crowd, Spero told of his own reasons for why he was behind Parents' Day:

We should all have love for dad and mother every day, but Parents' Day on the second Sunday in May is a reminder that both parents should be loved and respected together. No home can be happy where there is division of respect and affection.... The name daddy sounds good to all of us, and the name mother brings joy to our hearts. My mother, my dad-when we can say this with that real affection that makes you feel like giving mother a good kiss and dad a good hug (“Sets Parents' Day for city’s children," 1931).

Taking a line from the speech, Spero made "A Kiss for Mother, A Hug for Dad" the Parents' Day slogan and had it embossed on buttons that were distributed at campaign events (retrospectively noted in "Parents' Day fete is set for May 12," 1935).

In certain respects, the new slogan would seem to erase the cultural divide between fatherhood and motherhood. The use of dad did coincide with the way many fathers were addressed at the time (as they are today), and it may have demonstrated Spero's efforts to emphasize men's non-authoritarian side and not-just-a-breadwinner rolecharacteristics associated with the early 20th century "New Fatherhood" campaigns. The slogan, however, may also have connoted something else, something that Spero perhaps did not intend (or maybe did). In the 1920s and 1930s, the use of dad as a form of address was enmeshed in a culture of daddyhood, a cognitive schema that often accentuated men's child-playmate status and, at the same time, made fathers satirical targets (LaRossa). Thus, in other respects, the use of the informal idiom when referring to men without doing the same when referring to women (i.e., dad vs. mother) con- 
veyed the traditional idea that there were gendered differences when it came to parenting.

This raises another point. Although the Parents' Day campaign set out to merge Father's Day and Mother's Day as national symbols, it was not about equalizing fathers' and mothers' contributions to routine child care (the diaper changing, middle-of-thenight feedings, etc.). In fact, at no time was the division of child care said to be a major concern. Rather, if and when Spero focused on fatherhood, he tended to focus on men's other roles (e.g., setting a good example for children). He may have chosen to do so because he thought he could get more support from the educational and political establishment - and thus make more of an impression on the press - by zeroing in on childrearing duties that classroom teachers and elected officials would embrace. The campaign to replace Father's Day and Mother's Day no doubt would have ended sooner, had it not attracted the media. Nonetheless, by sidestepping the question of routine childcare, Spero's agenda was more conservative than not. In this sense, too, the Parents' Day campaign mirrored the early 20th century "New Fatherhood" campaigns, which also generally did not interrogate ideologies that said women should be primarily responsible for the "dirty work" associated with having children (Griswold, 1993; LaRossa).

On Mother's Day, 1931, Spero-along with the Mayor of New York, the Superintendent of Schools, and "several thousand school children and parents" - gathered on the Mall to promote Parents' Day ("Let schools alone, Walker demands, defending system," 1931). Testimonials about fathers and parenthood at a Parents' Day rally would be anticipated. But, from news reports, one might think that the group had assembled for an educational policy summit, because most speeches (which were broadcast on WNYC, the municipal radio station) centered not on fatherhood or parenthood, but on the New York City school system. One statement read during the festivities, however, did explicitly focus on Parents' Day. Forwarded by French Strother, administrative assistant to Herbert Hoover, it said simply: "The President directs me to say that you are at liberty to use the following message for the celebration of Parents' Day in Central Park on May 10th: 'The love and respect of parents and children are the root of a very large part of all the happiness in the world"" ("Walker to address parents tomorrow," 1931).

President Hoover expressed his support for Parents' Day the following year as well: "The finest partnership in the world is the partnership of father, mother, and children in the business of making one another happy." Mayor Walker also sent a missive: "If my mother was alive she wouldn't want any day set apart from her pleasure where my dad couldn't share in fame" ("Hoover lauds family ties," 1932). Governor (soon to be President) Roosevelt offered, in addition:

It is with great pleasure that I commend in the highest terms your efforts in the suitable observance of Parents' Day on the second Sunday in May. I hope you will convey to the youngsters who will join with you my affectionate feelings. As to the parents, no one has a greater estimate of what you term "the greatest of partnerships." In 
truth, they are the bulwark of the American home. ("Hoover lauds Parents' Day," 1932)

Spero predicted that 50,000 people would gather on the Mall in 1932. Rain, however, forced the cancellation of the event. Rescheduled a week later, the Parents' Day rally drew a much smaller crowd, closer to 10,000 . Once again, the speeches by the various invitees centered less on fatherhood or parenthood than on education and politics (“Walker enlivens Parents' Day fete," 1932).

As to the order of events at a Parents' Day rally, typically the festivities would begin with greetings from Spero and perhaps the President of the local Parent Teacher Association. Then, the Star Spangled Banner and various other anthems would be played. Next, the Mayor, Superintendent of Schools, and other invited dignitaries each might give an address. A child sometimes led the gathered in song. (See, for example, the program outlined in "40,000 expected for Parents' Day," 1936.) If and when a speech or presentation happened to focus on Parents' Day, endorsements would be offered all around-sometimes from the dais, sometimes from the crowd.

Spero generally was able to control both the information that went out about Parents' Day and the order of festivities at the rallies, and virtually every article in the Times gave the impression that support for the Parents' Day campaign was unanimous, at least among those in attendance. One article, however, reported that, at the 1936 Parents' Day rally, someone took the unusual step of voicing disapproval of the holiday. New York City Works Progress Administration director, Victor F. Ridder, gave a short address in which he offered: "Uncle Robert wants me to make this Parents' Day, but it will always be Mother's Day with me. You will never know how grateful to her you ought to be until you find out what she does for you. You mean more to your mothers than any of the men gathered here today, and that is as it ought to be." As soon as Ridder finished his remarks, Spero jumped to the microphone to proclaim: "Now remember, pals, this is Parents' Day, no one-sided event. We want fathers to be more than just a meal ticket” (“20,000 in park pay honor to parents," 1936). Worth mentioning is the fact that advance reports about the 1936 Parents' Day rally did not list Ridder as a speaker. Ridder thus may have been a last minute substitute whose views on Parents' Day were not screened.

From 1933 to 1938, Parents' Day celebrations grew more and more elaborate. Each year there would be the usual politicos - the Mayor, a State Senator or two, the Superintendent of Schools. But along with these dignitaries there were now other players. In 1933, Spero honored a husband and wife who had 16 children and who, on the basis of their fecundity, were judged to have the largest family in New York City ("Family of 18 wins Parents' Day honors," 1933; "Largest family eats in 3 shifts," 1933). A New York City chapter of the Boy Scouts of America also sent 1,000 scouts to the Parents' Day festivities that year ("Scouts back Parents' Day," 1933). In 1936, a man and woman, both 91 years old and together for 70 of those years, were pronounced to be Greater New York's longest married couple ("Called New York's 'ideal parents,", 1936). In 1937, Spero introduced five "Gold Star" couples, one from each of the city's 
boroughs. ("Gold Star" status meant that they had lost a child in World War I.) ("20,000 pay homage to city's parents," 1937). And in 1938, there was a "Parade of Nations," made up of 28 youngsters who, according to Spero, represented "most races which have had a major part in forming New York's "melting pot'" ("Parents' Day fete to be held today," 1938).

Spero continued to announce each year that he anticipated crowds numbering between 40,000 and 50,000. At no time, however, did that many actually show up. From 1933 to 1937, respectively, post-event estimates in the Times were: 10,000, 20,000, $15,000,20,000$, and 20,000. In 1938, the paper simply reported that the audience was "large." Even though Spero's attendance estimates were always off the mark, he benefited by putting the estimates in his press releases. Because the Times generally did not point out the discrepancy between the predicted and actual numbers, newspaper readers easily could get an inflated impression of the overall popularity of the campaign. This would be especially true for those individuals who did not attend the rallies and who had seen only the pre-event articles.

Was the Parents' Day campaign confined to New York? The Times reported in 1931 that, in addition to organizing his own Parents' Day rally, Spero had "sent thousands of letters to clergymen of all denominations throughout the country, requesting they hold appropriate Parents' Day services" ("Parents Day fete planned for 40,000," 1931). In 1932, Spero claimed he had "received assurances of cooperation" from the Governor of Arkansas and the Mayor of Baltimore ("Children to mark Parents' Day May 8," 1932); and in 1933, the Governor of California reportedly issued a Parents' Day proclamation (“"Parents' Day' gains," 1933). Also, in 1933, Rutgers University was said to have held its seventh annual Parents' Day celebration ("Honor to parents to be paid today," 1933), and the Superintendent of Schools in Jersey City was credited with sending memos to his teachers "asking them to hold appropriate ceremonies" on the Friday before Mother's Day (“Backs Parents' Day plan,” 1933). Queried in 1936 about the popularity of Parents' Day beyond New York, Spero responded: "Many school officials and Governors from all over the country have sent letters pledging their support of Parents' Day. Some of them plan to hold their own celebrations . . .." (“40,000 expected for Parents' Day," 1936). Finally, in 1937, there was a small news article that may have had nothing to do with Spero's aims, but did suggest that Parents' Day was an idea that had some international support. Said the Times: "Equal rights for fathers were recognized by [Filipino] President Manual Queson when he abolished Mother's Day. In its place he created Parents' Day, the first Monday of December" (“Queson creates Parents' Day,” 1937).

In 1939, the Parents' Day festivities were supposed to have been held at the World's Fair site in Queens ("Parents' Day celebration," 1938). When the second Sunday in May came, however, they were scheduled again in Central Park. No explanation was given for the change. In contrast to the numbers posted in prior years, only 6,000 celebrants were in attendance at the rally (“6,000 on Park Mall mark Parents' Day," 1939).

The 1939 event was the last Spero would attend and, from what we can gather from newspaper reports, the last the city would see. In April, 1940, at the age of 77, 
Spero announced that he was retiring and no longer would be leading the Parents' Day campaign. The Times intimated that the recent death of his wife- "who had been his companion for forty-seven years and who had aided him in all of his activities"prompted his decision ("Uncle Robert," 1940; Mrs. Robert Spero, 1940).

Although Spero was unable to continue to promote Parents' Day, he was confident the campaign would continue. Along with announcing he was stepping down, he assured everyone the 1940 Parents' Day rally would take place. Moreover, he said he had "arranged to perpetuate Parents' Day . . . by handing its management over to the Parents' Magazine, the president of which is George J. Hecht" ("Uncle Robert," 1940).

The selection of Hecht to take charge the Parents' Day campaign would seem to be a brilliant move. Hecht was someone who had written an editorial 11 years before in support of Parents' Day, and who, as the publisher of the most successful parenting magazine in the country, had the resources to keep the Parents' Day campaign going. Who better to champion Parents' Day? Hecht, however, proved to be a poor choice.

The second Sunday in May of 1940 came and went without a Parents' Day rally being mentioned in the New York Times. Then, in March, 1941, the Times reported: "To promote the observance of Mother's Day, May 11, the National Committee on the Observance of Mother's Day has been incorporated, it was announced by George J. Hecht, publisher of Parents' Magazine and chairman of the committee. . . The 1941 slogan of the committee is: "Remember mother! She never forgets!"” ("Mother's Day is promoted," 1941).

Why Hecht chose to abandon Parents' Day and throw his support behind Mother's Day is not known. Whatever his motivation, his departure left the Parents' Day campaign without a leader and effectively ended the campaign.

Robert Spero died on December 13, 1948, at the age of 86. The New York Times credited him with having "created National Parents' Day," but devoted most of its obituary to Spero's philanthropic work. All that was said about the campaign was, "His Parents' Day celebration, held annually for many years on the Mall in Central Park, drew thousands of spectators" ("Robert Spero, 86, children's friend, 1948).

Today, the Parents' Day campaign has been basically deleted from America's collective memory. Rarely, if ever, is it talked about.

\section{Why Did the Parents' Day Campaign Fail?}

The Parents' Day campaign did not reach a point where it could be considered a full-fledged social movement. The idea of merging Father's Day and Mother's Day never really caught on with the public.

A social movement, according to one definition, is "a set of opinions and beliefs in a population which represents preferences for changing some elements of the social structure and/or reward distribution of a society" (McCarthy \& Zald, 1977, pp. 12171218). Along with the opinions and beliefs, there must be a formal or informal organization, or a group of actors, to push a movement's agenda. Social movements also are said to have four elements. They "make claims on the state or some other authority 
seen to have the capacity to redress activist grievances." They "challenge cultural codes and transform the lives of their participants." They "use means in addition to those offered and accepted by mainstream politics." And they "are comprised of a diverse field of organizations and actors working in pursuit of the same general goals" (Meyer, 2000, pp. 39-40).

The Parents' Day campaign had certain features that may have made it look like a social movement. Its stated objective was to change a nation's commemoration structure and re-calibrate the distribution of parental rewards. Given that Mother's Day was a federal holiday, the campaign also was making claims on the U.S. government. Because Father's Day and Mother's Day were national symbols, Spero was challenging America's cultural codes as well. The opinions and beliefs underlying the campaign generally focused on the idea that fathers were important to children and that having separate holidays for fathers and mothers was unfair. These opinions and beliefs were espoused by a variety of individuals, some of whom were very prominent. As for its political methods, the Parents' Day campaign relied on mail-outs and one (very orderly) demonstration each year. By this measure, the campaign was within the mainstream.

Ultimately, the Parents' Day campaign did not have the numbers to qualify as a social movement. No more than 20,000 individuals ever showed up at a Parents' Day rally. Virtually all were from the New York metropolitan region. Of those who attended, many were schoolchildren whose presence probably was at the behest of their teachers.

If Spero had remained at the helm of the campaign, he might have been able to gather more followers as time went on. Central to the success of a campaign - and (on a larger scale) a social movement - are the tangible and intangible resources that can be assembled in support of collective action. Simply put, money, labor, equipment, media access, etc. help to get things started and keep things going (Jenkins, 1983). Spero had the means to do what others might not have been able to do. As "Uncle Robert," he could grab the media's attention; and being financially well off, he had the funds and office staff to send out promotional materials (which he did in the thousands). As a philanthropist, he was in a position to court major endorsements.

The actions of Spero's successor also contributed to the campaign's downfall. George Hecht's decision to head up the National Committee on the Observance of Mother's Day rather than take the reins of the Parents' Day campaign, as he had promised he would do, was fatal. Given that he had endorsed Parents Day in a 1929 editorial in Parents' Magazine, it also was unexpected. One possible motivation for Hecht's actions is that, when he penned his editorial, he believed Parents' Day better reflected the mission of his periodical. At the time, Parents' Magazine had been in circulation for only three years and its market was less defined. Throughout the 1930s, when Hecht and Spero were working in concert, Hecht also may have thought that Parents' Magazine would appeal to fathers as well as mothers, as indicated by the "For Father's Only" magazine column that he boldly initiated in 1932 and then unceremoniously dropped in 1937 (LaRossa). By 1941, however, Parents' Magazine clearly had become a periodical for mothers and its circulation had soared (Schlossman, 1985). In the final analysis, Hecht simply may have opted to stand by his customer base. 
Someone else could have taken up the Parents' Day campaign, but did not (as far as we know from published reports). But even if a high-profile individual had stepped forward, it may not have been enough to make much of a difference. Nine months after Hecht became head of the Mother's Day Committee, the United States was involved in World War II. All signs indicate that the war helped to boost Father's Day and Mother's Day as national observances. Americans wanted to thank parents of young soldiers for their sacrifice and recognize fathers who were being shipped overseas. Reflecting this sentiment, "Father, The Defender of the Home" was chosen as the 1942 Father's Day slogan (by the Father's Day Committee, a New York City based business organization) (“Mayor Unveils Poster," 1941). Promoters of Parents' Day could have tried to use the war to emphasize the communal anguish in America's homes and make the case that parents should be honored as a group. But there is a good reason to believe they would have run into difficulty selling this idea, since when a soldier died in battle it almost always was assumed that the women in the family were the ones who suffered the greater loss. "Gold Star" status, to honor the death of a son or daughter in uniform, was generally awarded not to couples, as was the case at the 1937 Parents' Day rally, but to mothers (History, American Gold Star Mothers, Inc., 2008).

Regardless of whether Spero remained at the helm and regardless of the war, the Parents' Day campaign probably still would have failed, because of the institutionalized support that Father's Day and Mother's Day had by the late 1930s. Granted, the two holidays may not have been perceived to have the highest level of legitimacy, but their legitimacy was nevertheless high. Assemblyman Berg believed that "nothing" would "be lost" by substituting Parents' Day for Mother's Day, but he grossly underestimated how popular Mother's Day was in the 1920s and 1930s and, more importantly, who was benefiting from it. Consider, for example, where people of faith stood on the matter. Berg said that he was able to secure the backing of a "clergy club," and Spero told the Times that he had sent letters to ministers asking them to promote Parents' Day. Other evidence, however, indicates that religious leaders stood strongly behind Mother's Day (see Schmidt).

As an alternative to Mother's Day, Parents' Day may have contained more ambiguity than the clergy was willing to allow. The 1920s and 1930s were decades when ideas about gender and family were in flux (Coontz, 2005; Filene, 1998; Mintz \& Kel$\operatorname{logg}$, 1988). Women had won the right to vote in 1920 and had entered the job market at a higher rate than before (though their representation was not close to what it is today). Men were being told to be more "domestic" and less obsessed with breadwinning. To some, the "New Woman" and "New Man" were refreshing and long overdue. To others, the changes spelled trouble. Modernists were of the opinion that America was at the dawn of a new and very promising era, while traditionalists, whose influence increased after women got the right to vote (Evans), wanted Victorian concepts of femininity and masculinity to prevail. What Mother's Day offered the clergy, who tended to be conservative on matters of gender, was an opportunity to remind women of their "true calling." Mother's Day symbolized the idea that a woman's proper place was in the home with their children, not in a factory or office alongside men. 
Then there were the commercial interests that supported both Father's Day and Mother's Day. Against these forces, the Parents' Day campaign was no match. One might suppose that merchants would find changing Father's Day and Mother's Day to Parents' Day an appealing idea. At the time, Father's Day had nowhere near the commercial power of Mother's Day. Combining the holidays could increase the number of gifts for dad. Not many in the business community, however, expressed support for Parents' Day. (At least, there was little indication of support in the Times, which, by contrast, offered detailed reports of the business community's support for Father's Day.) Merchants may have believed the key to the financial success of Mother's Day was the degree to which it was reified, that is, perceived as a non-socially constructed event, in the realm of the cosmic or sacred (Berger \& Luckmann). Dropping Mother's Day for Parents' Day would have been a little like combining Thanksgiving and the Fourth of July. Such a conversion may have been categorized as "unholy" (de-sanctifying both) and carry with it the risk of confusing and alienating shoppers who, in order to feel comfortable with spending scarce Depression-era funds, had to believe that Mother's Day was an ontologically-ordained observance. After Father's Day became more accepted, merchants may have been even less willing to combine Father's Day and Mother's Day, because having Father's Day follow Mother's Day guaranteed a more protracted selling season.

\section{What If the Parents’ Day Campaign Had Succeeded?}

Does it make any difference that Parents' Day failed? If holidays are viewed only as epiphenomena, then we would not bother to ask such a question. The fact is, however, annual celebrations are agents or sites for mnemonic socialization and thus serve as cognitive framing devices (Zerubavel, 1997, 2003).

American consumers spend about \$16 billion on Mother's Day and \$10 billion on Father's Day (National Retail Federation, 2007a \& b). Eliminate either holiday and the economy might suffer. It should not be assumed, however, that merging Father's Day and Mother's Day would necessarily reduce overall sales, or that, if it did, the effect would be permanent. Products and services come and go all the time. If the Parents' Day campaign had won out, resulting in one less commemoration, someone probably would have invented another holiday to take its place. (Even the modern version of Christmas is an "invented tradition" [Nissenbaum, 1996].) The existence of Parents' Day might have facilitated, for example, the institutionalization of Grandparents' Day which, at present, though it is listed on many printed calendars, has not been widely embraced. Yet, with people living longer and with children having more of an opportunity to know their grandparents and, in some settings, be raised by their grandparents, a Grandparents' Day could be viewed as a legitimate holiday. Were it to catch on, retailers would be ecstatic.

One way to imagine what might have happened if Parents' Day had been recognized by Congress is to examine other holidays that do not single out one person or social position. Consider, for example, Valentine's Day. Historically, there could have 
developed not a single Valentine's Day but two- one for women and one for men, with the gift recipient being one gender or the other, depending on the date. This actually is what happens in Japan, where Valentine's Day (February 14) is a day on which women give chocolates to men, while White Day (March 14) is a day on which men give chocolates (or cakes) to women. In contrast, the United States has a single Valentine's Day on which both men and women exchange gifts. (For more on the history of Valentine's Day, see Schmidt.)

The United States' version of Valentine's Day, more so than Father's Day and Mother's Day, blurs the conventionally defined romantic boundaries between men and women. We do not mean to suggest that the reproduction of gender distinctions is absent on Valentine's Day, for, as anyone can readily see, the gifts that are exchanged on February 14 generally conform to traditional gender stereotypes. Still, what is less likely to happen on Valentine's Day than on Father's Day and Mother's Day - and what might have been less likely to happen on Parents' Day - are commercial activities that are decidedly one sided. We are struck, for example, by the fact that our local newspaper used to encourage readers to place Mother's Day greetings in the Classifieds, but did not offer the same opportunity for Father's Day. Valentine's Day greetings, however, were offered to all.

Lastly, an argument could be made that a Parents' Day is more sensitive to family diversity. What should be done in a pre-school classroom the week before Father's Day or Mother's Day? Should the teacher help the children make cards and trinkets to give as gifts? But suppose, as is likely, some of the children live in single-parent homes where a father or mother is not a major presence? What then? Children being raised by gay and lesbian parents might also find Father's Day and Mother's Day awkward at times. So might youngsters under the custody of grandparents or other relatives. Parents' Day, being a more generic holiday - a celebration of caregiving regardless of gender or sexual orientation or kinship tie - might be seen as more in sync with complex family situations.

\section{Conclusion}

The culture of parenthood is comprised of not just the norms, values, and beliefs that pertain to fathers and mothers, but also the expressive symbols that are associated with fatherhood and motherhood (LaRossa). Included among these symbols are the ceremonies and rituals that are designed to honor the men and women who have taken it upon themselves to raise daughters and sons.

It is not uncommon for Father's Day and Mother's Day to be thought of as fixed entities that each year trigger purchases amounting to billions of dollars. But Father's Day and Mother's Day also are socially constructed realities and, as such, exist only in and through the work of various individuals and interest groups to legitimate the holidays (Berger \& Luckmann). The tale of the Parents' Day campaign helps to convey not only how social realities are built and reinforced (for Parents' Day was a socially constructed reality, too), but also how seemingly "hardened" social realities may be scrutinized and challenged. 
The campaign to eliminate Father's Day and Mother's Day and substitute Parents' Day was a skirmish, albeit minor, over how fathers and mothers should be memorialized and hence culturally located. Given that people's identities are intimately linked to the memories they have (Gergen \& Gergen, 1997; Gillis, 1994), an understanding of the social meaning of fatherhood and motherhood requires some knowledge of parental commemoration. Symbolic boundaries are based, in part, on what is deemed appropriate to recall.

\section{References}

Backs Parents' Day plan: Head of Jersey City schools to join Uncle Robert's program. (1933, April 12). New York Times, p. 22.

Benford, R. D., \& Snow, D. A. (2000). Framing processes and social movements: An overview and assessment. Annual Review of Sociology, 26, 611-639.

Berger, P. L., \& Luckmann, T. (1966). The social construction of reality: A treatise in the sociology of knowledge. New York: Doubleday/Anchor.

Blumer, H. (1969). Symbolic interactionism: Perspective and method. Englewood Cliffs, NJ: Prentice-Hall.

Called New York's “ideal parents”: Mr. and Mrs. George Lurcott of Brooklyn. (1936, May 8). New York Times, p. 24.

Children to mark Parents' Day May 8: 50,000 will attend exercises on Central Park Mall, Uncle Robert predicts. (1932, April 24). New York Times, p. II-3.

Coontz, S. (1992). The way we never were: American families and the nostalgia trip. New York: Basic.

Coontz, S. (2005). Marriage, A history: From obedience to intimacy or how love conquered marriage. New York: Viking.

Drop Mother's Day plan: Clash of women's organizations stops children's celebration. (1923, May 13). New York Times, p. II-2.

Earl, J., Martin, A., McCarthy, J. D., \& Soule, S. A. (2004). The use of newspaper data in the study of collective action. Annual Review of Sociology, 30, 65-80.

Evans, S. M. (1989). Born for liberty: A history of women in America. New York: Free Press.

Family of 18 wins Parents' Day honors: Adjudged the largest in the city, it will appear at exercises at park May 14. (1933, May 10). New York Times, p. 19.

Father's Day, Public Law 92-278, 86 stat. 124 [H. J. Res. 687]: Joint resolution to authorize the President to designate the third Sunday in June of each year as Father's Day. (Approved 1972, April 24). U.S. Code Congressional and Administrative News, Volume 1, 92nd Congress, 2nd Session.

Filene, P. (1998). Him/her/self: Sex roles in modern America (Third Edition). Baltimore: Johns Hopkins University Press.

40,000 expected for Parents' Day: Mayor, Ridder, and Campbell to speak at Uncle Robert's fete in park next Sunday. (1936, May 6). New York Times, p. 10.

Gergen, K. J., \& Gergen, M. M. (1997). "Narratives of the self." In L. P. Hinchman \& S. K. Hinchman (Eds.), Memory, identity, and community: The idea of narrative in the human sciences (pp. 161-184). Albany, NY: State University of New York Press.

Gillis, J. R. (1994). Memory and identity: The history of a relationship. In J. R. Gillis (Ed.), Commemorations: The politics of national identity (pp. 3-24). Princeton, NJ: Princeton University Press.

Griswold, R. L. (1993). Fatherhood in America: A history. New York: Basic Books. 
Happiest couple sought: Uncle Robert wants longest wed in city for Parents' Day fete. (1936, March 15). New York Times, p. 3.

Harte, J. (1994, June 19). [Why the heck is Father's Day so far from Mother's Day?] B.C. Creators Syndicate, Inc.

Hecht, G. J. (1929, May). Why not Parents' Day? An editorial message. Children, The_Parents' Magazine, p. 16. [This was original title of the magazine. In the 1930s, it was Parents' Magazine. Today, it is Parents magazine.]

History, American Gold Star Mothers, Inc. Retrieved July 17, 2008, from http://www.goldstarmoms.com/WhoWeAre/History/History.htm

Honor to parents to be paid today: Mother's Day, with fathers included, will be observed by gifts and ceremonies. (1933, May 14). New York Times, p. II-1.

Hoover lauds family ties: Uncle Robert gets Parents' Day message from Walker also. (1932, April 9). New York Times, p. 13.

Hoover lauds Parents' Day: Other notables commend exercises planned by Uncle Robert. (1932, April 16). New York Times, p. 8.

Jenkins, J. C. (1983). Resource mobilization theory and the study of social movements. Annual Review of Sociology, 9, 527-553.

Kimmel, M. (1996). Manhood in America: A cultural history. New York: Free Press.

Largest family eats in 3 shifts: Mother of 16 runs house on a timetable-honor set for Sunday upset it. (1933, May 11). New York Times, p. 19

LaRossa, R. (1997). The modernization of fatherhood: A social and political history. Chicago: University of Chicago Press.

Let schools alone, Walker demands, defending system: Mayor at Parents' Day fete bids critics direct fire at him, not education board. (1931, May 11). New York Times, p. 1.

Many celebrations mark Mothers' Day. (1923, May 14). New York Times, p. 15.

Mayor unveils poster. (1941, November 16). New York Times, p. 40.

McCarthy, J. \& Zald, M. (1977). Resource mobilization and social movements: A partial theory. American Journal of Sociology, 82, 1212-1241.

Meyer, D. S. (2000). Social movements: Creating communities of change. In R. L. Teske \& M. A. Tetreault (Eds.), Conscious acts and the politics of change (pp. 35-55). Columbia, SC: University of South Carolina Press.

Mintz, S., \& Kellogg, S. (1988). Domestic revolutions: A social history of American family life. New York: Free Press.

Mothers at odds on day: War body protests attack on its sale of carnations. (1924, May 4). New York Times, p. X-8.

Mother's Day, Inc. (1938, May 16). Time, pp. 17-18.

Mother's Day is promoted. (1941, March 2). New York Times, p. 41.

Mrs. Robert Spero: Wife of Uncle Robert, founder of Parents' Day, is dead. (1940, January 19). New York Times.

National Retail Federation. (2007a). Mom to enjoy royal treatment this year, according to NRF. Retrieved June 25, 2007, from http://www.nrf.com/modules.php?name=News\&op=viewlive \&sp_id=269

National Retail Federation. (2007b). Consumers aren't out of gas when it comes to dad. Retrieved June 25, 2007, from http://www.nrf.com/modules.php?name=News\&op=viewlive \& sp_id=304

Nissenbaum, S. (1996). The battle for Christmas. New York: Knopf.

Parents' Day celebration. (1938, June 18). New York Times, p. 17.

Parents Day fete planned for 40,000. (1931, May 3). New York Times, p. II-1.

Parents' Day fete is set for May 12: Uncle Robert announces plans for annual celebration on Central Park Mall. (1935, March 3). New York Times, p. II-3. 


\section{LAROSSA AND CARBOY}

Parents' Day fete to be held today: Feature of celebration on Central Park Mall to be "parade of 28 nations." (1938, May 8). New York Times, p. II-1.

"Parents' Day" gains: California proclamation ordering observance received here. (1933, May 21). New York Times, p. II-5.

Public hearing for "Parents' Day." (1930, February 2). New York Times, p. II-2.

Queson creates Parents' Day. (1937, October 15). New York Times, p. 24.

Says mothers favor day for both parents: Assemblyman Berg confident of adoption of his bill to designate one. (1930, January 26). New York Times, p. II-4.

Schlossman, S. (1985). Perils of popularization. The founding of Parents' Magazine. In A. Boardman Smuts \& J. W. Hagen (Eds.), History and research in child development (pp. 65-77). Monographs of the Society for Research in Child Development, Volume 50, No. 4-5, Serial No. 211.

Schmidt, L. E. (1995). Consumer rites: The buying and selling of American holidays. Princeton, NJ: Princeton University Press.

Scouts back Parents' Day: Boys urged to attend program in park on May 14. (1933, May 3). New York Times, p. 19.

Second Sunday in May: Mother's Day finds promoter of idea poor, hospitalized, and still bitter. (1944, May 8). Newsweek, pp. 35-36.

Sets Parents' Day for city's children: Uncle Robert to lead annual tribute on Sunday, May 10, on Central Park Mall. (1931, March 15). New York Times, p. II-6.

6,000 on Park Mall mark Parents' Day: Dr. Campbell and other city leaders join in tributes many children present. (1939, May 15). New York Times, p. 12.

20,000 in park pay honor to parents: Mayor marks day with gift of "Champaign Pavilion" turned into playground. (1936, May 11). New York Times, p. 5.

20,000 pay homage to city's parents: Mayor joins in mass tribute to mothers and fathers on Central Park Mall. (1937, May 10). New York Times, p. 7.

Uncle Robert, 77, is soon to retire: Parents Day originator says magazine will give program. (1940, April 20). New York Times, p. 27.

Walker enlivens Parents' Day fete: Youthful throng of 10,000 in park cheers Mayor and greets him as "pal." (1932, May 16). New York Times, p. 17.

Walker to address parents tomorrow: Dr. O'Shea and Senator Berg also will speak at Uncle Robert's exercises in park. (1931, May 9). New York Times, p. 19.

Walker to deliver tribute to parents: Chosen by Uncle Robert as the chief speaker at Central Park next Sunday. (1932, May 1). New York Times, p. 12.

Why not a home day? And thus honor fathers, mothers, and children at the same time. (1916, May 26). New York Times.

Zerubavel, E. (1997). Social mindscapes: An introduction to cognitive sociology. Cambridge, MA: Harvard University Press.

Zerubavel, E. (2003). Time maps: Collective memory and the social shape of the past. Chicago: University of Chicago Press. 